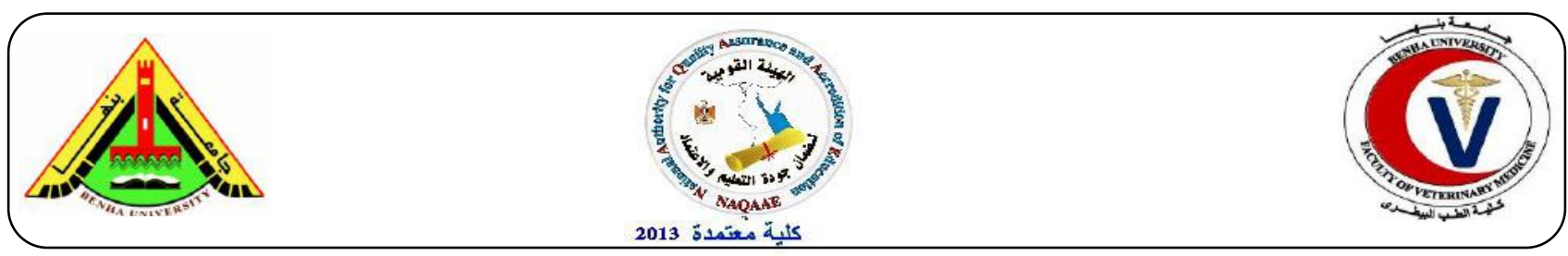

\title{
Clinicopathological and Ultrasonographic Changes during Experimentally Induced Arthritis in Donkey
}

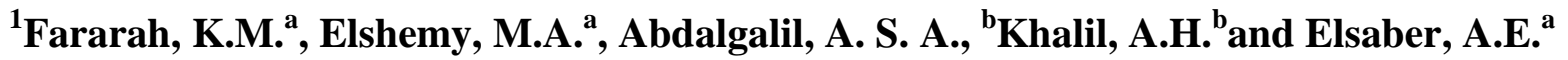 \\ Clinical Pathology Dep. Fac. Vet Med. Benha Univ. ${ }^{a}$,
}

Surgery Dep. Fac. Vet.Med. Benha Univ. ${ }^{b}$

\section{A B S T R A C T}

This study was intended to verify the clinicopathological effect of intra-articular (IA) staph aureus and amphotericin B injection in the carpal joints of donkeys to induce arthritic changes and to correlate it with the histopathological findings. Six healthy, adult donkeys of both sexes. Animals were numbered and divided into two groups; each group consists of three animals. ${ }^{\text {st }}$ group is used for induction of septic carpitis in the right radiocarpal joints of donkeys by Staph. aureus with a dose of $3 \times 10^{6} \mathrm{cfu}$ as a single intra-articular injection. The $2^{\text {nd }}$ group is used for induction of osteoarthritis in the radiocarpal joints of donkeys by $20 \mathrm{mg}$ amphotericin B in $3 \mathrm{ml}$ sterile water as a single intra-articular injection. Whereas the left joint was the control in both groups .Two ml Synovial fluid and serum were taken at 0, 1, 3,7,13 days after administration and tissues samples of Joint capsule and synovial membrane at 13 days. Sampling at zero day was considered as control. Clinical assessment, synovial fluid analysis, ultrasonography and histopathological examinations were done. Total leukocytic count, total protein Amyloid A, IL-1 $\beta$ and CRP concentrations sharply increased on 1, 3, 7, 13days 7 after induction of the experiment when compared with their control at zero. .There were significant changes in amyloid A, IL-1 $\beta$ and CRP in septic cases when compared with aseptic cases of arthritis. The results obtained confirm that the concentrations of total leukocytic count, total protein amyloid A, IL-1 $\beta$ and CRP increase substantially in equine septic arthritis and osteoarthritis which provides a theoretical basis for the rapid diagnosis of the diseases and to distinguish between septic arthritis and non-septic synovitis by a variety of diagnostics.

Keywords: Equine, Staph aureus, ultrasonography, osteoarthritis, amyloid A, synovial fluid.

\section{(http://www.bvmj.bu.edu.eg)}

(BVMJ-35(1): 250-262, 2018)

\section{INTRODUCTION}

Arthritis is a self-perpetuating, progressive joint disease (Holderbaum, Malvitz et al. 2005)and is one of the most commonly orthopedic problems, both in human and animals(Boileau, Martel-Pelletier et al. 2004).
Septic arthritis in adult horses occurs most commonly in association with traumatic wounds and can become life-threatening due to difficulties clearing established infections and development of degenerative changes associated with ongoing 


\begin{abstract}
inflammation(Lugo and Gaughan 2006). Only $56-81 \%$ of horses return to their original function following treatment for septic arthritis(Wright, Smith et al. 2003). Early diagnosis is critical to rapid resolution of infection and inflammation to avoid ongoing cartilage degradation and osteoarthritis(Ludwig 2016).
\end{abstract}

Osteoarthritis (OA) is one of the most common causes of lameness and poor performance in the horse(Caron and Genovese 2003).

Synovial fluid is a viscous, mucinous substance that lubricates most joints. Analysis of synovial fluid is important in the diagnosis of joint disease(Ludwig 2016).

Examination of the synovial fluid should be a routine procedure in the evaluation of arthritic conditions, as it can provide valuable information in addition to that gained by clinical and radiologic examination(Morton 2005).

Septic synovial fluid is classically characterized by marked elevations in total protein (TP) and total nucleated cell count (TNCC). However, in some cases it can be difficult to distinguish between synovial infection and acute non septic synovial inflammation based on clinical signs and synovial fluid cytology alone. A variety of other diagnostics can be used to help distinguish between septic arthritis and nonseptic synovitis such as amyloid A ,IL1 $\beta$ and CRP (Morton 2005).

During the development of acute phase response, APR release pro-inflammatory cytokines interleukin-1 (IL-1), interleukin-6 (IL-6) and tumor necrosis factor (TNF- $\alpha$ ) that act through different receptors on the membrane of hepatocytes, certain proteins synthesized in the so-called acute phase proteins (APPs), including: serum amyloid A (SAA), haptoglobin, fibrinogen, C-reactive protein (CRP), ceruloplasmin and $\alpha 1$-acid glycoprotein(Ceron, Eckersall et al. 2005).
Serum amyloid A, the major acute phase protein in horses, increases systemically in response to injury, infection, and inflammation(Jacobsen and Andersen 2007).

Ultrasonography has been used historically in the evaluation of horses with suspected septic synovitis. It allows evaluation of periarticular wounds, joint effusion, the quality of the synovial fluid, synovial inflammation, presence of foreign bodies, and involvement of soft tissues.

The aims of this study are 1) To assess the effect of Staph aureus in inducing septic arthritis and to correlate the clinical findings with the Ultrasonography and histopathological changes.

2) To assess the effect of amphotericin $B$ in inducing aseptic arthritis and to correlate the clinical findings with the ultrasonography and histopathological ones.

3) To distinguish between septic arthritis and non-septic synovitis by a variety of diagnostics including as amyloid $\mathrm{A}, \operatorname{IL} 1 \beta$, CRP,Ultra sonography and histopathological ones.

\section{MATERIALS AND METHODS}

\subsection{Induction of arthritis:}

In this study, six healthy, adult donkeys of both sexes.aging between 2-4 years and weighing between 150-200 $\mathrm{kg}$ were numbered and divided into two groups, were treated as following

$1^{\mathrm{ST}}$ Group (Septic Group): Three donkeys are used for induction of septic carpitis in the right radiocarpal joints of donkeys by Staph. Aureus $3 \times 10^{6} \mathrm{cfu}($ Elkasapy, AbdelGalil et al., 2014).The left carpal joint of control.

$2^{\text {nd }}$ Group (A Septic Group): Three donkeys were injected aseptically into the right radiocarpal joint with $20 \mathrm{mg}$ amphotericin B in $2 \mathrm{ml}$ sterile water as a single intra-articular injection. The left carpal joint of control (Hulten and Demmers 2002).

\subsection{Sampling:}




\subsubsection{Synovial fluid sampling}

(Arthrocentesis):

Two ml Synovial fluid were aspirated on EDTA from most joints with a one inch, 18 to 20gauge needle. The skin should be prepared by clipping the hair and performing a surgical scrub to avoid introducing bacteria into the joint. Ethyl chloride spray may be used. Synovia samples were used for quantitative determination of total leukocytic count by hemocytometer (Mundt and Shanahan 2010), TP(Vassault, Grafmeyer et al. 1986), A (AA)(Ludwig 2016),(CRP) (Yamashita, Fujinaga et al. 1991) and (IL1 $\beta)$ (Pelletier, Martel-Pelletier et al. 2001)by using ELISA.

\subsubsection{Serum samples:}

Blood was collected in plain clean well-dried centrifuge tube for separation of serum to be used in estimation of biochemical parameters. The collected blood samples were allowed to clot and serum samples were obtained by centrifugation at 3000 revolution per minute for 15 minutes. Sera were obtained by automatic pipette and transferred into clean dry labeled Eppendorf tubes and kept in deep freeze till examination.

Blood samples were collected from jugular vein at zero day for control and at 1.3.7.13day. Serum samples were used for quantitative determination of Total protein(Vassault, Grafmeyer et al. 1986),Serum Amyloid A (SAA)(Ludwig 2016), C Reactive Protein (CRP)(YamashitaA, Fujinaga et al. 1991)and Interleukin $1 \quad \beta \quad(\mathrm{IL} 1 \beta)$ (Pelletier, MartelPelletier et al. 2001)by using ELISA.

\subsubsection{Tissue specimens:}

Joint Capsule and Synovial membrane specimens:At 13day at the end of the experiment Joint Capsule and Synovial $\mathrm{mm}$ specimens were placed in $10 \%$ formalin solution for histopathological investigations.
Skin preparation over the carpal region was achieved by hair clipping, shaving, scrubbing with warm water and soap and touching with alcohol.Ultrasonography examination was performed according to (Denoix 2009). Ultrasound machine (Ultrasound VET Magic-2200) with adjusted 6 $\mathrm{MHz}$ linear array probe was satisfactory for examination. All examinations were achieved with flexed carpus, with machine gain (75) and probe depth $(3 \mathrm{~cm})$. Different Ultrasonographic measurements including joint capsule thickness, extensor carpiradialis tendon thickness and joint space width were evaluated and recorded.

Quantitative assessment of joint space echogenicity was achieved according to(Mostafa, Al-Akraa et al. 2016)by image brightness analysis (on gray scale units from 0 (black) to 255 (white)) by using dedicated software(Image J) to obtain the mean gray value of the analyzed image.

\subsection{Histopathological examination:}

Autopsy samples were taken from the joint capsule and synovial membrane from right and left carpal joint in both groups at 13 days of experment and fixed in $10 \%$ formal saline for twenty- four hours. Washing was done in tap water then serial dilutions of alcohol (methyl, ethyl and absolute ethyl) were used for dehydration. Specimens were cleared in xylene and embedded in paraffin at 56 degree in hot air oven for twenty- four hours. Paraffin bees wax tissue blocks were prepared for sectioning at 4 microns thickness by slide microtome. The obtained tissue sections were collected on glass slides, deparaffinized, and stained by hematoxylin and eosin stain for examination through the light electric microscope(Bancroft and Designed ByCunningham 1996). 


\subsection{Statistical analysis:}

The statistical analysis was carried out using two-way ANOVA using SPSS, ver. 22(Released 2013) Data were treated as a complete randomization design according to(Steel, 1980 )Multiple comparisons were carried out applying Duncun test The significance level was set at $<0.05$

\section{RESULTS}

Serum and synovial fluid samples were collected at $0,1,3,7$ and 13 days after I/A injection of Staph. aureus. $3 \times 10^{6} \mathrm{cfu}$ and/or I/A injection of $20 \mathrm{mg}$ amphotericin B.

The following results were obtained:

3. 1. Effect of arthritis on TLC of synovia:

Data demonstrating the effects of arthritis on TLC are summarized in table (1)

Our results showed that TLC in the synovia were significantly increased in the donkeys with septic arthritis on days 1, 3 and 7 after induction of the experiment when compared with their control at zero day Meanwhile, there were non-significant changes in the TLC in the 13 days of septic arthritis when compared to the zero day. Regarding to a septic arthritis group there were significant increases in TLC in the 1 and 3 days when compared to zero day. Meanwhile, there were non-significant changes in TLC in the 7 and 13 days when compared to the zero day.

Furthermore, there were significant increase in TLC in septic cases when compared to aseptic cases of arthritis at 1 and 3 days there were no significant increase in TLC in the 7 and 13 days.

\subsection{Effect of arthritis on Total protein:}

Data demonstrating the effects of arthritis on total protein are summarized in table (2) Our data showed that the concentrations of total protein in synovia were significantly increased in donkeys with septic arthritis on days 1, 3, and 7 after induction of the experiment when compared with their control at zero day. Meanwhile, there were no significant changes in the 13 days when compared with the zero day. There was no a significant changes in the concentrations of total protein in the synovia in septic group when compared with aseptic group. Similarly, the concentrations of total protein in the serum showed the same pattern and significance of synovial concentrations except that there was significant increase in the total protein in septic cases when compared with aseptic cases at 1 and 13 days

\subsection{Effect of arthritis on Amyloid A:}

The results of amyloid $\mathrm{A}$ in synovia and serum were depicted in table (3) Our results showed that the concentrations of amyloid A in synovia were significantly increased in the donkeys with septic arthritis on days 1, 3, 7 and 13 after induction of the experiment when compared with their control at zero day .There were significant increase in amyloid A in septic cases when compared with aseptic cases of arthritis. Similarly, amyloid A in the serum showed the same pattern and significance of synovial concentrations

\subsection{Effect of arthritis on $C R P$ :}

The results of CRP in synovia and serum were depicted in table (4) Our results showed that the concentrations of CRP in synovia were significantly increased in the donkeys with septic arthritis on days 1, 3, 7 and 13 after induction of the experiment when compared with their control at zero day IN aseptic cases of arthritis the concentrations of CRP in synovia were significantly increased on days 1, 3, 7 and 13 after induction of the experiment when compared with their control at zero day. There were no significant differences in CRP between septic and aseptic cases except in the 7 days. Similarly, C R P in the serum showed the same pattern and significance of synovial concentrations. There were significant changes in the 3 and 7 days between septic and aseptic groups.

\subsection{Effect of arthritis on ILI $\beta$ :}


Data demonstrating the effects of arthritis on IL1 $\beta$ are summarized in table (3). Our data showed that the concentrations of IL $1 \beta$ in synovia were significantly increased in donkeys with septic arthritis on days 1, 3, 7 and 13 after induction of the experiment when compared with their control at zero day. IL1 $\beta$ concentration reached to the highest concentration at 1day of septic group which was higher than the highest concentration of aseptic group at the same day .Similarly, the concentrations of IL $1 \beta$ in the serum showed the same pattern and significance of synovial concentrations.

\subsection{Ultra-sonographic examinations:}

Ultra-sonographic examination of both the septic and aseptic groups at 3rd day post induction revealed wider area of more echogenic synovial cavity (joint effusion), thick hyperechoic joint capsule and the Extensor carpi radialis tendon appeared thicken and less echogenic than normal fig (1)

\subsection{Histopathological finding:}

Semi-quantative scanning of histopathological lesions revealed marked increase of inflammatory synovitis lesions in animals subjected to intra articular injection of $\mathrm{S}$. aureus while animal injected with amphotericin $b$ showed marked increase of stromal tissue proliferation table (7)fig (2,3 and 4).

Regarding to histological finding, synovial membrane of control groups showed normal thin layer of synovial cells consisted mostly from one cell layer which surrounded with vascularized alveolar connective tissue.

Animal injected with S. aureus (on articular basis) revealed marked increase synovial cells hypertrophy and hyperplasia, which also showed focal desquamation, leave ulcers.

The sub intimal layer showed extensive inflammatory reaction mostly lymph plasma cells (indicating chronic synovitis).

The most predominant feature is the perivascular cuffing which consisted mainly from lymphocytes.

Animal subjected to intra articular injection of amphotericin b demonstrated mild to moderate degree of synovial cells hyperplasia .Also there was mild degree of sub -intimal inflammatory cells infiltration (mainly lymphocyte).

The most feature in this type of synovitis is the proliferation of stromal fibroblast like cells

Table (1):TLC changes in synovia after I/A injection of Staph. aureus. $3 \times 10^{6} \mathrm{cfu}$ and/or I/A injection of $20 \mathrm{mg}$ amphotericin $\mathrm{B}$.

\begin{tabular}{ccc}
\hline Period (days) & $\begin{array}{c}\text { Septic } \\
\text { Synovia }\end{array}$ & A septic \\
\hline 0 (Control) & $650.00 \pm 86.60^{\mathrm{dA}}$ & $744.67 \pm 58.95^{\mathrm{dA}}$ \\
1 & $184000.00 \pm 8717.80^{\mathrm{aA}}$ & $16666.67 \pm 1763.83^{\mathrm{aB}}$ \\
3 & $10333.33 \pm 881.92^{\mathrm{bA}}$ & $6200.00 \pm 416.33^{\mathrm{bB}}$ \\
7 & $6600.00 \pm 305.51^{\mathrm{bcA}}$ & $5366.67 \pm 578.31^{\mathrm{bdA}}$ \\
13 & $3000.00 \pm 288.68^{\mathrm{cdA}}$ & $2866.67 \pm 290.59^{\mathrm{bdA}}$ \\
\hline
\end{tabular}


Table (2):Total protein concentrations changes in synovia, serum and Differentiation between serum and synovia after I/A injection of Staph. aureus. $3 \times 10^{6} \mathrm{cfu}$ and/or I/A injection of $20 \mathrm{mg}$ amphotericin B.

\begin{tabular}{ccc}
\hline Period (days) & $\begin{array}{c}\text { Septic } \\
\text { Synovia }\end{array}$ & A septic \\
\hline 0 (Control) & $1.70 \pm 0.26^{\mathrm{cA}}$ & $2.03 \pm 0.14^{\mathrm{dA}}$ \\
1 & $6.15 \pm 0.32^{\mathrm{aA}}$ & $6.13 \pm 0.38^{\mathrm{aA}}$ \\
3 & $4.00 \pm 0.49^{\mathrm{bA}}$ & $3.60 \pm 0.40^{\mathrm{cA}}$ \\
7 & $4.20 \pm 0.21^{\mathrm{bA}}$ & $4.31 \pm 0.59^{\mathrm{bA}}$ \\
13 & $2.10 \pm 0.20^{\mathrm{cA}}$ & $2.10 \pm 0.06^{\mathrm{bcA}}$ \\
& Blood & \\
$0($ Control $)$ & $3.92 \pm 0.04^{\mathrm{bA}}$ & $3.97 \pm 0.12^{\mathrm{cA}}$ \\
1 & $9.17 \pm 0.59^{\mathrm{aA}}$ & $7.67 \pm 0.43^{\mathrm{aB}}$ \\
7 & $8.07 \pm 0.67^{\mathrm{aA}}$ & $6.90 \pm 0.86^{\mathrm{abA}}$ \\
13 & $7.87 \pm 1.00^{\mathrm{aA}}$ & $4.90 \pm 0.26^{\mathrm{bB}}$ \\
\hline
\end{tabular}

Table (3): Amyloid A concentrations changes in synovia, serum and Differentiation between serum and synovia after I/A injection of Staph. aureus. $3 \times 10^{6} \mathrm{cfu}$ and/or I/A injection of $20 \mathrm{mg}$ amphotericin B.

\begin{tabular}{ccc}
\hline Period (days) & Septic & A septic \\
\hline $0($ Control $)$ & $\underline{\text { Synovia }}$ & \\
1 & $4.97 \pm 0.41^{\mathrm{eA}}$ & $4.60 \pm 0.38^{\mathrm{eA}}$ \\
3 & $84.33 \pm 2.33^{\mathrm{aA}}$ & $42.80 \pm 1.83^{\mathrm{aB}}$ \\
7 & $60.67 \pm 1.45^{\mathrm{bA}}$ & $27.37 \pm 0.64^{\mathrm{bB}}$ \\
13 & $31.67 \pm 0.88^{\mathrm{cA}}$ & $24.33 \pm 0.88^{\mathrm{cB}}$ \\
& $19.00 \pm 1.53^{\mathrm{dA}}$ & $15.67 \pm 0.88^{\mathrm{dB}}$ \\
$0($ Control $)$ & $\underline{B l o o d}$ & \\
1 & $11.27 \pm 0.50^{\mathrm{eA}}$ & $10.00 \pm 0.58^{\mathrm{eA}}$ \\
3 & $115.5 \pm 2.96^{\mathrm{aA}}$ & $58.33 \pm 1.45^{\mathrm{aB}}$ \\
7 & $83.67 \pm 1.86^{\mathrm{bA}}$ & $41.67 \pm 0.88^{\mathrm{bB}}$ \\
13 & $42.80 \pm 0.69^{\mathrm{cA}}$ & $30.33 \pm 0.88^{\mathrm{cB}}$ \\
\hline
\end{tabular}


Table (4): CRP concentrations changes in synovia, serum and Differentiation between serum and synovia after I/A injection of Staph. aureus. $3 \times 10^{6} \mathrm{cfu}$ and/or I/A injection of $20 \mathrm{mg}$ amphotericin B

\begin{tabular}{ccc}
\hline Period (days) & Septic & A septic \\
& Synovia & \\
\hline 0 (Control) & $0 \pm 0^{\mathrm{eA}}$ & $0 \pm 0^{\mathrm{eA}}$ \\
1 & $11.33 \pm 0.33^{\mathrm{aA}}$ & $12.00 \pm 0.00^{\mathrm{aA}}$ \\
3 & $10.67 \pm 1.45^{\mathrm{bA}}$ & $10.00 \pm 1.53^{\mathrm{bA}}$ \\
7 & $6.33 \pm 0.88^{\mathrm{cB}}$ & $7.67 \pm 0.88^{\mathrm{cA}}$ \\
13 & $3.00 \pm 0.58^{\mathrm{dA}}$ & $2.00 \pm 0.58^{\mathrm{dA}}$ \\
& Blood & $0 \pm 0^{\mathrm{dA}}$ \\
$0($ Control $)$ & $0 \pm 0^{\mathrm{dA}}$ & $14.6 \pm 0.33^{\mathrm{aA}}$ \\
1 & $13.33 \pm 1.33^{\mathrm{aA}}$ & $12.4 \pm 0.88^{\mathrm{bA}}$ \\
3 & $11.67 \pm 1.45^{\mathrm{bB}}$ & $6.00 \pm 0.58^{\mathrm{cA}}$ \\
7 & $6.67 \pm 0.67^{\mathrm{cB}}$ & $5.00 \pm 0.58^{\mathrm{cA}}$ \\
\hline
\end{tabular}

Table (5):IL1 $\beta$ concentrations changes in synovia, serum and Differentiation between serum and synovia after I/A injection of Staph. aureus. $3 \times 10^{6} \mathrm{cfu}$ and/or I/A injection of $20 \mathrm{mg}$ amphotericin B.

\begin{tabular}{ccc}
\hline Period (days) & Septic & A septic \\
& Synovia & \\
\hline 0 (Control) & $91.67 \pm 4.41^{\mathrm{eA}}$ & $86.00 \pm 3.06^{\mathrm{eA}}$ \\
1 & $1231.00 \pm 9.54^{\mathrm{aA}}$ & $916.67 \pm 8.82^{\mathrm{aB}}$ \\
7 & $660.00 \pm 20.82^{\mathrm{bB}}$ & $687.33 \pm 6.36^{\mathrm{bA}}$ \\
13 & $430.67 \pm 19.68^{\mathrm{cB}}$ & $590.00 \pm 5.77^{\mathrm{cA}}$ \\
& $328.00 \pm 13.32^{\mathrm{dA}}$ & $283.33 \pm 8.82^{\mathrm{dB}}$ \\
$0($ Control $)$ & Blood & $114.00 \pm 2.08^{\mathrm{eA}}$ \\
1 & $117.00 \pm 4.04^{\mathrm{eA}}$ & $1223.33 \pm 12.02^{\mathrm{aB}}$ \\
3 & $1562.33 \pm 9.06^{\mathrm{aA}}$ & $786.67 \pm 8.82^{\mathrm{bA}}$ \\
7 & $709.00 \pm 4.93^{\mathrm{bB}}$ & $689.33 \pm 5.81^{\mathrm{cA}}$ \\
13 & $596.33 \pm 3.76^{\mathrm{cB}}$ & $415.67 \pm 17.19^{\mathrm{dB}}$ \\
\hline
\end{tabular}

a, b \& c: There is no significant difference $(P>0.05)$ between any two means, within the same column have the same superscript letter.

A, B \& C: There is no significant difference $(P>0.05)$ between any two means for the same attribute, within the same row have the same superscript letter.

Table (6): Histological scoring of synovitis:

\begin{tabular}{lcccc}
\hline Groups & $\begin{array}{c}\text { Proliferation of } \\
\text { synovial cells }\end{array}$ & $\begin{array}{c}\text { Inflammatory } \\
\text { cells infiltration }\end{array}$ & $\begin{array}{c}\text { Stromal cell } \\
\text { activation }\end{array}$ & $\begin{array}{c}\text { Necrobiotic } \\
\text { changes }\end{array}$ \\
\hline Control & - & - & - & - \\
S. aureus & +++ & +++ & ++ & +++ \\
Amophotrecine & ++ & ++ & +++ & + \\
\hline
\end{tabular}

(- indicates absence of the lesion, + indicates mild lesions, ++ indicates moderate lesions, +++ indicates severe lesions and ++++ indicates severe diffuse lesions). 
Clinicopathological and Ultrasonographic Changes during Experimentally Induced Arthritis in Donkey
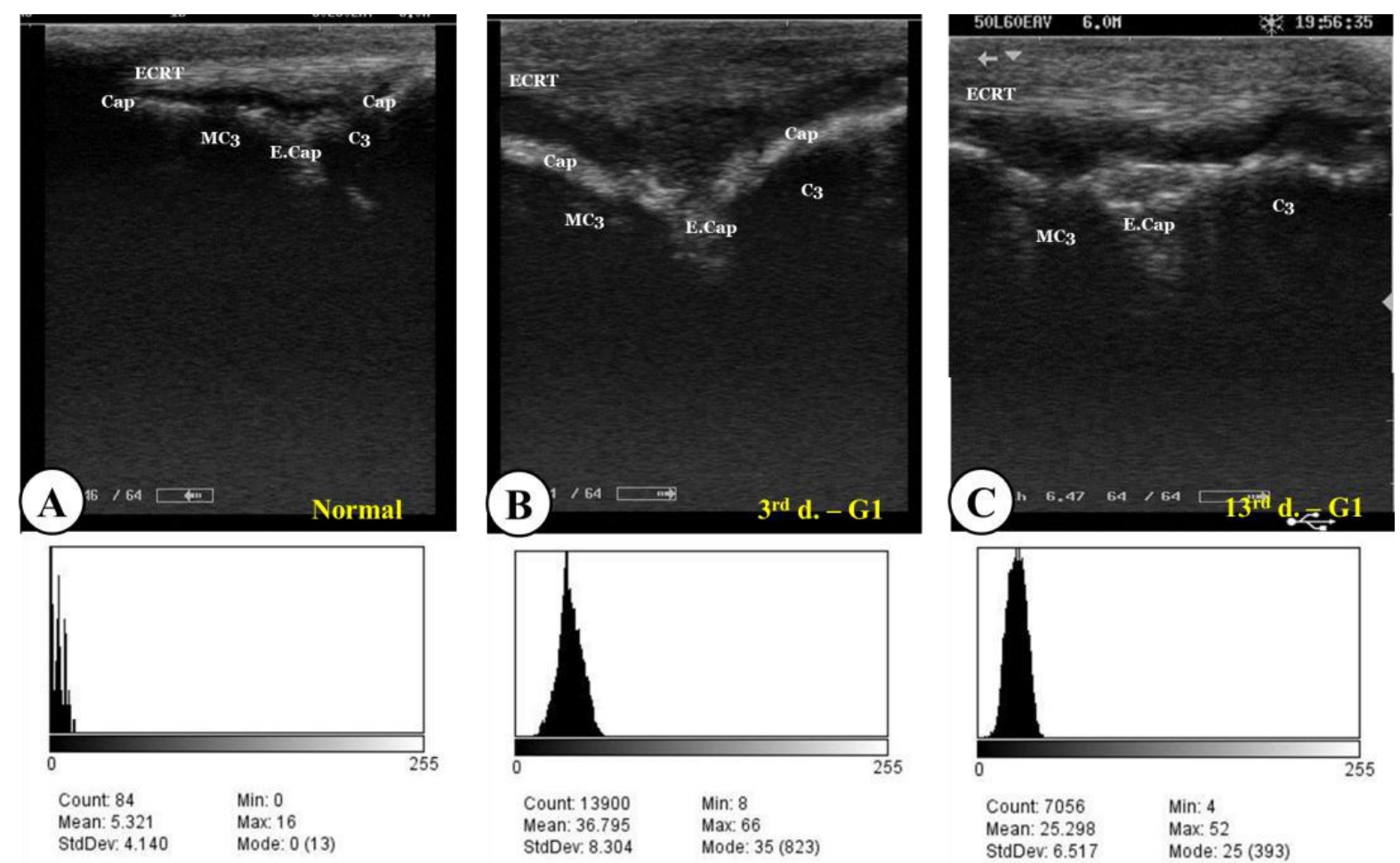

StdDev. 8.304

Mode: $35(823)$

Mode: 25 (393)
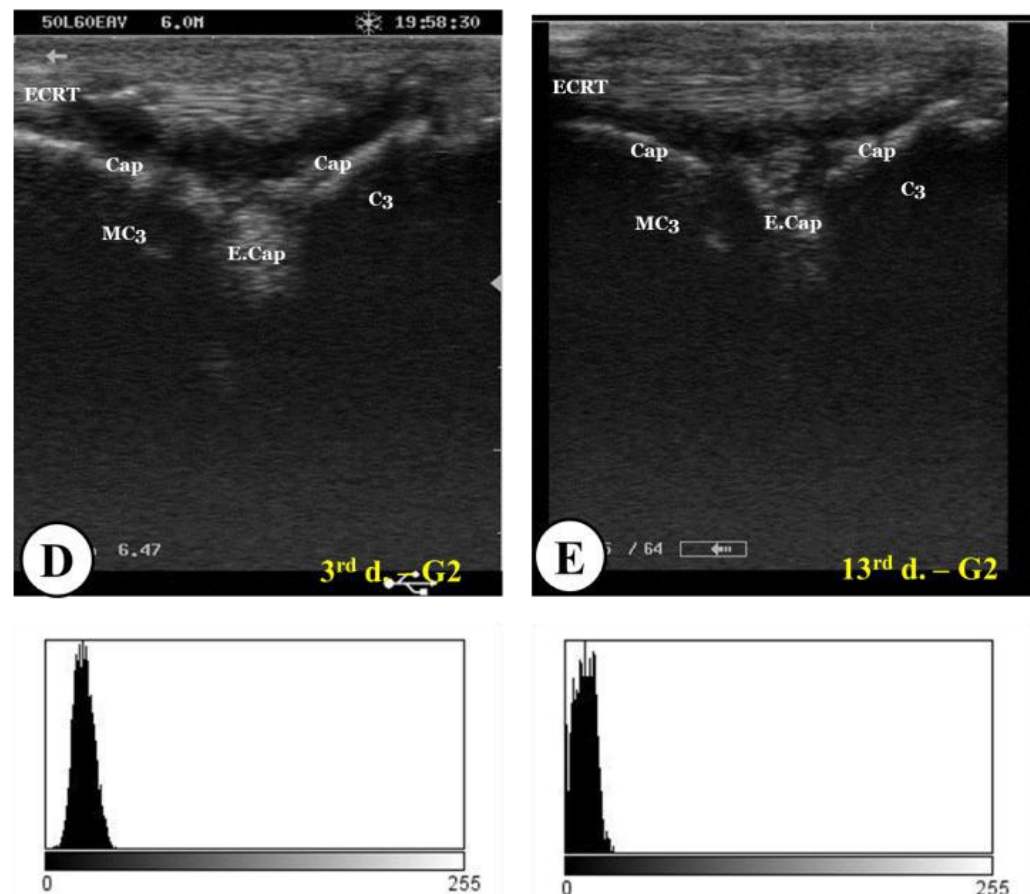

Count 5183 Mean: 22.667

Min: 3

Mode: $22(326)$

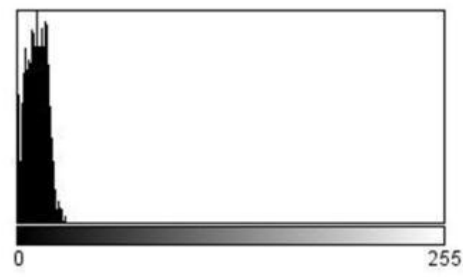

Count 3410 Mean: 10.968

Min: 0

StdDev. 6.182 StdDev. 6.073

Mode: 11 (204)

Fig. (1 ): Sagittal Ultra sonographic examinations of carpal joint of donkey with corresponding gray scale analysis of synovial cavity before induction (A), at $3^{\text {rd }}$ and $13^{\text {th }}$ days post induction of septic arthritis (B\&C respectively) and at $3^{\text {rd }}$ and $13^{\text {th }}$ days post induction of aseptic arthritis (D\&E respectively). 


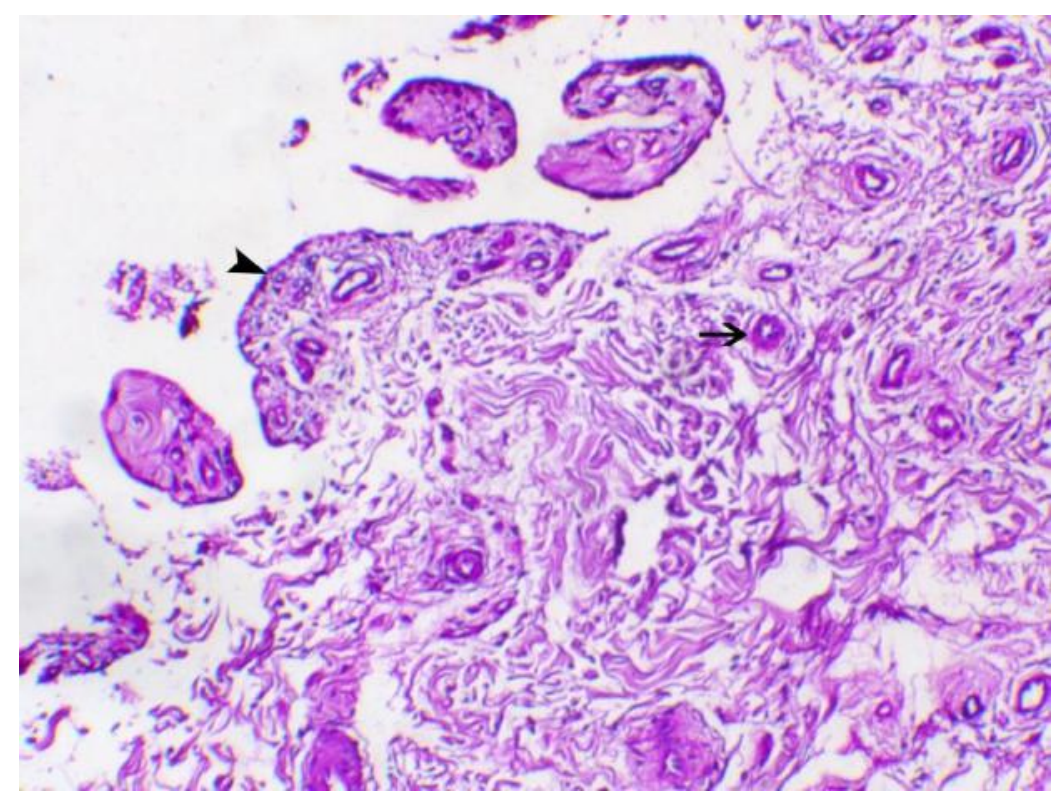

Fig. (2). Synovial sheath of control animal showing normal synovial membrane lined with intimal cell (arrowhead) and outlined with areolar connective tissue (arrow indicates vascularization of the connective tissue), $\mathrm{H} \& \mathrm{E}, \mathrm{X} 40$

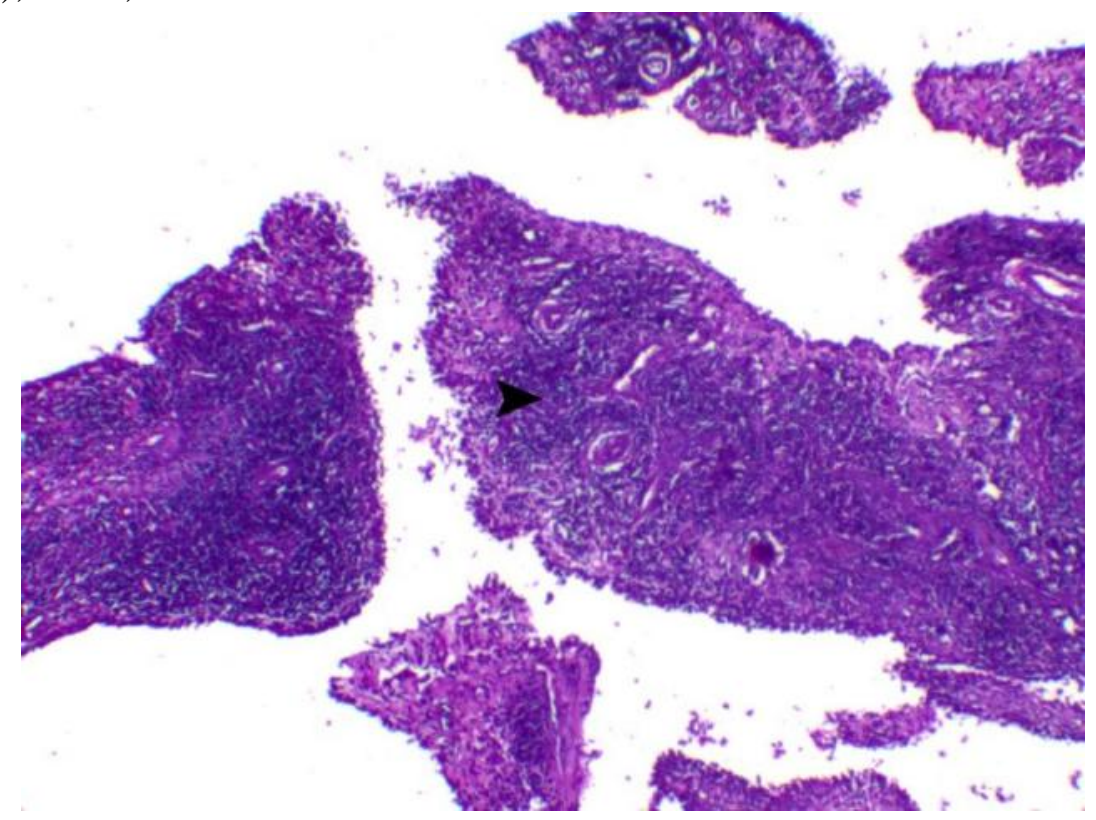

Fig. (3) Synovial sheath of intra-articular injected animal with S. aureus organism showing chronic synovitis associated with severe diffuse mononuclear cells infiltration within the outer connective tissue sheath (arrowhead), H\&E, X40. 


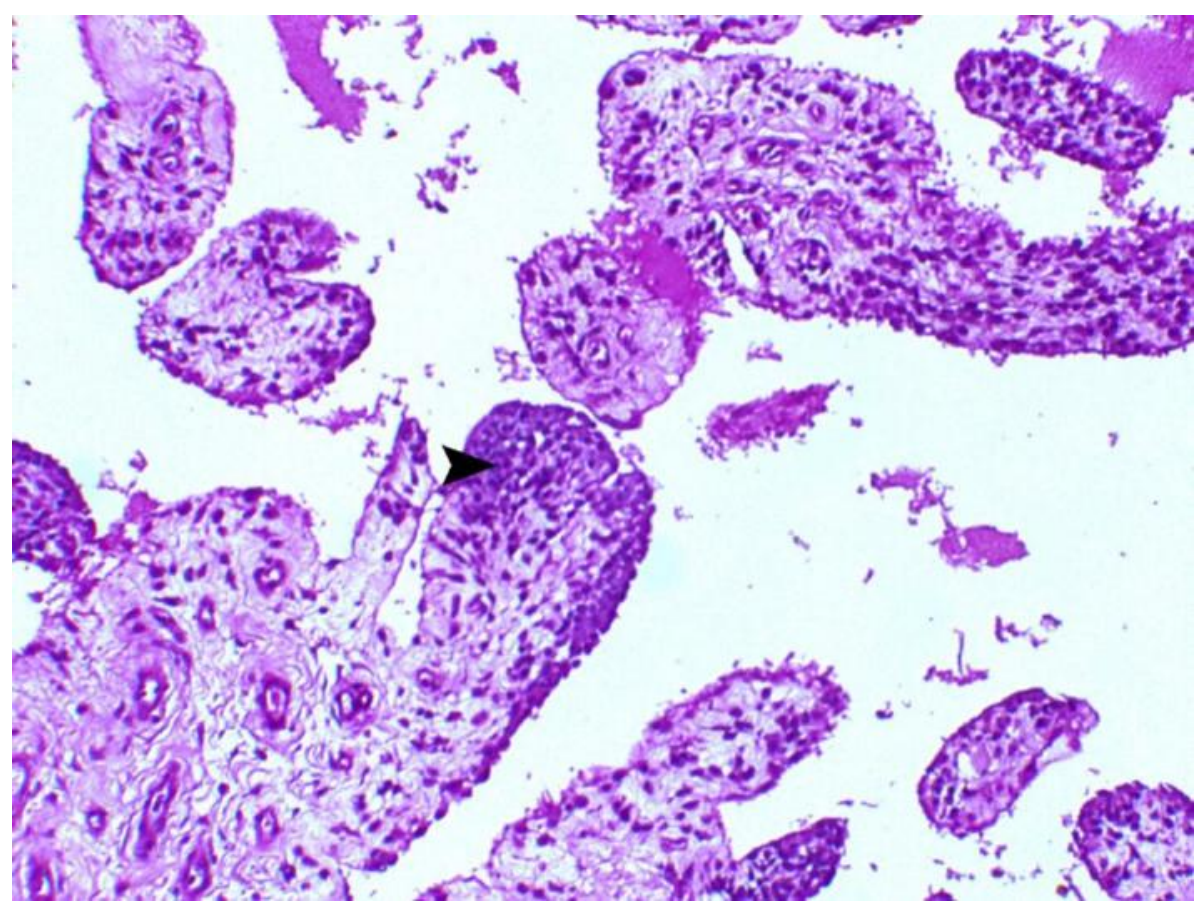

Fig. (4)Synovial sheath of amphotericin-treated animal showing mild degree of both intimal synovial cells proliferation and sub-intimal inflammatory cells infiltration (arrowhead), H\&E, X200.

\section{DISCUSSION}

In the present study, S. aureus was used in the induction of septic carpitis in donkeys because the most commonly isolated microorganisms from clinical cases was this microorganism in dose of $\left(3 \times 10^{6} \mathrm{CFU}\right)$ similar to that used by(Elkasapy, AbdelGalil et al. 2014).

In this study we use amphotericin B as model of chemically induced osteoarthritis in dose of Twenty $\mathrm{mg}$ of amphotericin B as a single IA injection in the right intercarpal joint similar to that used by(Hulten and Demmers 2002).

In this study, TLC in the synovia showed significant increase in the donkeys with septic arthritis on days 1, 3 and 7 after induction of the experiment when compared with their control at zero day. TLC in the synovia showed significant increase in a septic arthritis group in the 1 and 3 days when compared to zero day.
Our result agree with Steel (2008)who reported that TLC in synovia was increased in first stages of arthritis then gradually decreased by time .

Cases of infective arthritis have the highest white cell counts. In general, cell counts over $50,000 / \mathrm{mm} 3$ are indicative of infection and counts over 100,000 are virtually pathognomonic (Sevelius and Tufvesson 1963).

In this study, the concentrations of total protein in synovia and showed significant increases in the donkeys with septic and aseptic arthritis than control. our result agree with McBride (1998)who found that the normal range for synovial fluid protein is $1-3$ $\mathrm{g} / \mathrm{dL}$. Increased synovial fluid protein levels are seen in ankylosing spondylitis, arthritis, arthropathies that accompany Crohn disease, gout and psoriasis.

The protein content of synovial fluid from horses with inflammatory joint disease is 
consistently increased.This is attributable to increased synovial vascular permeability as well as breakdown of cellular elements within the exudate(Ludwig 2016).

In this study, the concentrations of amyloid A in synovia and serum showed significant increases in the donkeys with septic arthritis on days 1, 3, 7 and 13 after induction of the experiment when compared with their control at zero day .There were significant increase in amyloid A in septic cases when compared with aseptic cases of arthritis.

Our result agree with Ludwig( 2016).

Peak concentration of amyloid A in synovia and serum occurred on the first day and reached more than 10 time than control in case of septic cases and this result agree with Crisman, Scarratt et al. (2008)who reported that serum amyloid $\mathrm{A}$ is considered a major positive APP in horses as its concentration increases about 10 times during APR.

Marked difference in serum SAA between infection and inflammation have been used to help distinguish between infectious and noninfectious disease(Belgrave, Dickey et al. 2013).

In this study, the concentrations of CRP in synovia were significantly increased in the donkeys with septic and aseptic arthritis on days 1, 3, 7 and 13 after induction of the experiment when compared with their control at zero day. There were no significant differences in CRP between septic and aseptic cases except in the 7 days

Our result agree with Takiguchi, Fujinaga et al. (1990) who reported that a high serum concentration was also found in horses with pneumonia, enteritis, arthritis and after castration.

CRP is one of a minor APPs whose concentrations increase only 1-10 times during the APR(Jacobsen and Andersen 2007).

IL1 $\beta$ concentration reached to the highest concentration at 1 day of septic group which was higher than the highest concentration of aseptic group at the same day. This result agree with Koch, Lemmermeier et al.(1996) who reported that once colonized, bacteria are able to rapidly proliferate and activate an acute inflammatory response. Initially, host inflammatory cytokines, including interleukin 1- (IL-1) and interleukin 6 (IL-6), are released into the joint fluid by synovial cells then These cytokines activate the release of acutephase proteins (e.g., C-reactive protein) from the liver that bind to the bacterial cells and thereby promote opsonization and activation of the complement system(Osiri, Ruxrungtham et al. 1998).In our results the peak concentration ofIL1 $\beta$ occurred in serum and synovia at $1^{\text {st }}$ day of induction then gradually decreased. And this result agree with Osiri, Ruxrungtham et al. (1998)who found that IL-1 levels decreased significantly after 7 days of arthritis.

Normal ultra-sonographic examination of carpal joint revealed thin anechoic synovial cavity surrounding by thin hyperechoic capsule. The corresponding base line inflammatory markers including; Amyloid A were $4.97 \pm 0.41 \& 4.60 \pm 0.38$; IL1 $\beta$ were $91.67 \pm 4.41 \& 86.00 \pm 3.06$ and ALP were $7.40 \pm 1.80 \& 8.23 \pm 1.59$ for septic and aseptic groups respectively. This result coincided with Ludwig (2016).

Typical clinical signs of carpitis were revealed 24-72 hours post induction of both septic and aseptic groups including, swelling, pain and lameness. Moreover the ultrasonographic examination showed wider area of more echogenic synovial cavity (joint effusion), thick hyperechoic joint capsule and thicken decreased echogenic ECRT. There was a significant $(p \leq 0.05)$ increase of Gray value of synovial fluid, Tendon thickness and synovial cavity width. The corresponding results of inflammatory markers at the 72 
hours revealed significant $(p \leq 0.05)$ increase in correlation with baseline value.

Ultra-sonographic examination of both septic and aseptic groups at $3^{\text {rd }}$ day post induction revealed wider area of more echogenic synovial cavity (joint effusion), thick hyperechoic joint capsule and the ECRT appeared thicken and less echogenic than normal. Moreover, there was a significant $(p$ $\leq 0.05$ ) increase of Gray value of synovial fluid, Tendon thickness and synovial cavity width at $3^{\text {rd }}$ and $13^{\text {th }}$ days than normal value. However joint capsular thickness also showed significant $(p \leq 0.05)$ increase at $3^{\text {rd }}$ and $13^{\text {th }}$ days than normal value in septic group, in aseptic groups there was non-significant ( $p \leq$ 0.05 ) difference at the $13^{\text {th }}$ day. All parameters in aseptic group were significant $(p \leq 0.05)$ higher in septic group than aseptic group at 3rd and 13th d.

\section{REFERENCES}

Bancroft, N. H. and F. Designed By-Cunningham (1996). Implementing SAP r/3, Prentice Hall PTR.

Belgrave, R. L., M. M. Dickey, K. L. Arheart and C. Cray (2013). "Assessment of serum amyloid A testing of horses and its clinical application in a specialized equine practice." Journal of the American Veterinary Medical Association 243(1): 113-119.

Boileau, C., J. Martel-Pelletier, M. Guévremont, J. Pelletier, F. Poirier and P. Reboul (2004). "Galectin-3 in osteoarthritis: from a protective to a destructive role." Arthritis Res Ther 6(3): 20.

Caron, J. P. and R. L. Genovese (2003). Principles and practices of joint disease treatment. Diagnosis and Management of Lameness in the Horse, Elsevier: 746-764.

Ceron, J., P. Eckersall and S. S. Martynez (2005). "Acute phase

proteins in dogs and cats: current knowledge and future perspectives." Vet Clin Pathol 34: $85-99$.
Crisman, M. V., W. K. Scarratt and K. L. Zimmerman (2008). "Blood proteins and inflammation in the horse." Veterinary Clinics: Equine Practice 24(2): 285-297.

Denoix, J.-M. (2009). "Ultrasonographic examination of joints, a revolution in equine locomotor pathology."

Elkasapy, A., A. AbdelGalil, A. Al-Akraa, I. Ibrahim and S. Ismail (2014). "Arthroscopy of septic carpitis in donkeys (Equus asinus)." Open veterinary journal 4(2): 113117.

Holderbaum, D., T. Malvitz, C. Ciesielski, D. Carson, M. Corr and R. Moskowitz (2005). "A newly described hereditary cartilage debonding syndrome." Arthritis \& Rheumatology 52(10): 3300-3304.

Hulten, C. and S. Demmers (2002). "Serum amyloid A (SAA) as an aid in the management of infectious disease in the foal: comparison with total leucocyte count, neutrophil count and fibrinogen." Equine Veterinary Journal 34(7): 693-698.

Jacobsen, S. and P. H. Andersen (2007). "The acute phase protein serum amyloid A (SAA) as a marker of inflammation in horses." Equine Veterinary Education 19(1): 38-46.

Koch, B., P. Lemmermeier, A. Gause, J. Heisel and M. Pfreundschuh (1996). "Demonstration of interleukin-1beta and interleukin-6 in cells of synovial fluids by flow cytometry." European journal of medical research 1(5): 244-248.

Ludwig, E. K. (2016). Equine Septic Arthritis and Serum Amyloid A, Virginia Tech.

Lugo, J. and E. M. Gaughan (2006). "Septic arthritis, tenosynovitis, and infections of hoof structures." Veterinary Clinics: Equine Practice 22(2): 363-388.

McBride, L. J. (1998). Textbook of urinalysis and body fluids: a clinical approach, Lippincott.

Mcllwraith, C. (1980). "Synovial fluid analysis in the diagnosis of equine joint disease." Equine Pract 2: 44-48.

Morton (2005). " Diagnosis and treatment of septic arthritis." Vet Clin North Am Equine

Pract 21: 627-649. 
Mostafa, M., A. Al-Akraa and A. Khalil (2016). "Ultrasonographic assessment of superficial digital flexor tendon (SDFT) core lesion treated with platelet rich plasma (PRP) in donkeys (Equus Asinus)." BVMJ-29 (2): 274-282.

Mundt, L. A. and K. Shanahan (2010). Graff's textbook of routine urinalysis and body fluids, Lippincott Williams \& Wilkins.

Osiri, M., K. Ruxrungtham, S. Nookhai, Y. Ohmoto and U. Deesomchok (1998). "IL1 , IL-6 and TNF-a in Synovial Fluid of Patients with Non-Gonococcal Septic Arthritis." Asian Pacific journal of allergy and immunology 16(4): 155.

Pelletier, J. P., J. Martel-Pelletier and S. B. Abramson (2001). "Osteoarthritis, an inflammatory disease: potential implication for the selection of new therapeutic targets." Arthritis \& Rheumatology 44(6): 1237-1247.

Sevelius, F. and G. Tufvesson (1963). "Treatment for fractures of the sesamoid bones in horses." Journal of the American Veterinary Medical Association 142: 981.

Steel, C. M. (2008). "Equine synovial fluid analysis." Veterinary Clinics: Equine Practice 24(2): 437-454.

Steel, R. and J. C. TORRIE (1980). Principles and procedures of statistics: a biometrical approach, McGraw-Hill.

Takiguchi, M., T. Fujinaga, M. Naiki, S. Mizuno and K. Otomo (1990). "Isolation, characterization, and quantitative analysis of C-reactive protein from horses." American journal of veterinary research 51(8): 1215-1220.

Vassault, A., D. Grafmeyer, C. Naudin, G. Dumont, M. Bailly, J. Henny, M. Gerhardt and P. Georges (1986). "Protocole de validation de techniques." Ann Biol Clin 44(686): 45.

Wright, I., M. Smith, D. Humphrey, T. EatonEvans and M. Hillyer (2003). "Endoscopic surgery in the treatment of contaminated and infected synovial cavities." Equine veterinary journal 35(6): 613-619.
Yamashita, K., T. Fujinaga, M. Okumura, M. Takiguchi, N. Tsunoda and S. Mizuno (1991). "Serum C-reactive protein (CRP) in horses: the effect of aging, sex, delivery and inflammations on its concentration." Journal of Veterinary Medical Science 53(6): 1019-1024. 